\title{
Amycolatopsis palatopharyngis sp. nov., a potentially pathogenic actinomycete isolated from a human clinical source
}

Correspondence
Mariola Paściak
pasciak@immuno.iitd.pan.wroc.pl

\author{
Ying Huang, ${ }^{1}$ Mariola Paściak, ${ }^{2}$ Zhiheng Liu, ${ }^{1}$ Oiong Xie ${ }^{3}$ \\ and Andrzej Gamian²
${ }^{1}$ State Key Laboratory of Microbial Resources, Institute of Microbiology, Chinese Academy of Sciences, Beijing 100080, PR China
${ }^{2}$ Laboratory of Medical Microbiology, Institute of Immunology and Experimental Therapy, Polish Academy of Sciences, Rudolfa Weigla 12, 53-114 Wroclaw, Poland
${ }^{3}$ Institute of Space Medico-Engineering, Beijing 100094, PR China

The genus Amycolatopsis was established by Lechevalier et al. (1986) and was assigned to the family Pseudonocardiaceae (Embley et al., 1988; Warwick et al., 1994), which also contains the genera Actinopolyspora, Kibdelosporangium, Prauserella, Pseudonocardia, Saccharomonospora, Saccharopolyspora and Thermocrispum (Kim \& Goodfellow, 1999; Labeda \& Kroppenstedt, 2000; Huang et al., 2002). Recently, increasing interest has been shown in Amycolatopsis, as it contains strains that produce commercially significant bioactive compounds. Eight novel species with validly published names have been described during the last 3 years (Goodfellow et al., 2001; Huang et al., 2001; Lee \& Hah, 2001; Kim et al., 2002; Al-Musallam et al., 2003; Labeda et al., 2003). The 18 species of this genus phylogenetically form two groups, the Amycolatopsis methanolica and Amycolatopsis orientalis subclades (Kim et al., 2002). The A. orientalis subclade comprises 11 mesophilic species, Amycolatopsis alba, Amycolatopsis albidoflavus, Amycolatopsis azurea, Amycolatopsis coloradensis, Amycolatopsis japonica, Amycolatopsis keratiniphila, Amycolatopsis mediterranei, A. orientalis, Amycolatopsis pretoriensis, Amycolatopsis rubida and Amycolatopsis sulphurea (Huang et al.,

Published online ahead of print on 22 August 2003 as DOI 10.1099/ ijs.0.02685-0.

The GenBank/EMBL/DDBJ accession number for the $16 \mathrm{~S}$ rDNA sequence of $A$. palatopharyngis sp. nov. $1 \mathrm{BDZ}^{\top}$ is AF479268.
2001; Lee \& Hah, 2001; Kim et al., 2002; Al-Musallam et al., 2003; Labeda et al., 2003), and three moderately thermophilic species, Amycolatopsis kentuckyensis, Amycolatopsis lexingtonensis and Amycolatopsis sacchari, which grow at $45^{\circ} \mathrm{C}$ (Goodfellow et al., 2001; Labeda et al., 2003). The A. methanolica subclade comprises three thermophilic species, Amycolatopsis eurytherma, A. methanolica and Amycolatopsis thermoflava, which grow at temperatures above $50{ }^{\circ} \mathrm{C}$ (de Boer et al., 1990; Chun et al., 1999; Kim et al., 2002). The remaining thermophilic species, Amycolatopsis fastidiosa, which grows over a wide temperature range (10-60 $\left.{ }^{\circ} \mathrm{C}\right)$ (Henssen et al., 1987), is loosely associated with the others and forms a distinct phyletic line at the foot of the Amycolatopsis phylogenetic tree (Goodfellow et al., 2001; Huang et al., 2001; Lee \& Hah, 2001; Kim et al., 2002). In addition, Barreiro et al. (2000) also proposed that the cephamycin producer 'Nocardia lactamdurans' should be incorporated into the genus Amycolatopsis as 'Amycolatopsis lactamdurans', which falls into the A. orientalis subclade (Kim et al., 2002). Members of the genus Amycolatopsis can be distinguished from all other genera belonging to the family Pseudonocardiaceae by a combination of chemical and morphological properties (Kim \& Goodfellow, 1999).

In the present investigation, a polyphasic study was undertaken to determine the taxonomic position of a Grampositive, facultatively anaerobic strain, $1 \mathrm{BDZ}^{\mathrm{T}}$, which was isolated from a clinical sample of the palatopharyngeal 
mucosa of an elderly human patient. Genotypic and phenotypic data indicated that this strain should be classified as a novel species of the genus Amycolatopsis, for which we propose the name Amycolatopsis palatopharyngis sp. nov.

Strain $1 \mathrm{BDZ}^{\mathrm{T}}$ was isolated on a brain heart infusion agar plate that had been seeded using swabs and incubated at $37^{\circ} \mathrm{C}$ for 5 days under microaerophilic conditions. The clinical sample was collected from the infected palatopharyngeal mucosa of a 70-year-old male patient. The isolate was maintained on modified Bennett's agar (Jones, 1949) slants at $4{ }^{\circ} \mathrm{C}$ and as suspensions of mycelial fragments in glycerol $(20 \%, \mathrm{v} / \mathrm{v})$ at $-20^{\circ} \mathrm{C}$. Biomass for chemical and molecular systematic analyses was prepared as described previously (Huang et al., 2002) with the modification that the strain was grown at $37^{\circ} \mathrm{C}$ for $3-5$ days and cells were then killed by shaking with formalin $(1 \%, \mathrm{v} / \mathrm{v})$.

Cultural and morphological properties were observed using a Zeiss Axioskop 20 light microscope and a Hitachi S-570 scanning electron microscope after growth on modified Bennett's, glucose/yeast extract/malt extract (International Streptomyces Project medium 2; Shirling \& Gottlieb, 1966) and inorganic salt/starch agars (International Streptomyces Project medium 4; Shirling \& Gottlieb, 1966) for 7-14 days at $28^{\circ} \mathrm{C}$.

Phenotypic tests were carried out by following the procedures of Goodfellow et al. (1997) and Gordon et al. (1974). Antibiotic-resistance tests were performed using Bennett's medium and the method described previously (Huang et al., 2001).

Isomers of diaminopimelic acid and whole-cell sugars were analysed according to the procedures developed by Hasegawa et al. (1983) and Lechevalier \& Lechevalier (1980). Mycolic acids were checked by the acid methanolysis method of Minnikin et al. (1980). Polar lipids were examined by two-dimensional TLC and identified using the method of Minnikin et al. (1984). Menaquinones were extracted and purified as described by Collins (1985) and were analysed by HPLC (Wu et al., 1989). Cellular fatty acids were determined by treating dry cell mass $(2 \mathrm{mg})$ with $1 \mathrm{M}$ methanolic $\mathrm{HCl}(0.5 \mathrm{ml})$ at $80^{\circ} \mathrm{C}$ for $1 \mathrm{~h}$ and then extracting the fatty acid methyl esters liberated and analysing them directly using GLC-MS (Paściak et al., 2002). The $\mathrm{G}+\mathrm{C}$ content of the DNA was determined by using the thermal denaturation $\left(T_{\mathrm{m}}\right)$ method (Marmur \& Doty, 1962) with Escherichia coli AS 1.365 as the standard.

Genomic DNA preparation and PCR amplification of $16 \mathrm{~S}$ rDNA were performed by employing the method of Chun \& Goodfellow (1995). The amplified product was sequenced as described previously (Huang et al., 2001). The nucleotide sequence was obtained automatically by using an Applied Biosystems DNA sequencer (model 377) and software provided by the manufacturer. The $16 \mathrm{~S}$ rDNA sequence of strain $1 \mathrm{BDZ}^{\mathrm{T}}$ was aligned manually against corresponding sequences retrieved from the GenBank database using the CLUSTAL X 1.8 program (Thompson et al., 1997). Phylogenetic trees were inferred by using the neighbour-joining (Saitou \& Nei, 1987), least-squares (Fitch \& Margoliash, 1967) and maximum-likelihood (Felsenstein, 1981) treeing algorithms. Evolutionary distance matrices were generated as described by Kimura (1980). The resultant unrooted tree topologies were evaluated by bootstrap analyses (Felsenstein, 1985) of the neighbour-joining method, based on 1000 resamplings. The PHYLIP package (Felsenstein, 1993) was used for all phylogenetic analyses.

An almost complete $16 \mathrm{~S}$ rDNA sequence was obtained for strain $1 \mathrm{BDZ}^{\mathrm{T}}(1427 \mathrm{nt})$. Phylogenetic analysis in which this sequence was compared with corresponding sequences of representatives of the suborder Pseudonocardineae indicated that this strain belongs to the family Pseudonocardiaceae (data not shown). Further analysis, supported by a high bootstrap value of $100 \%$, showed that strain $1 \mathrm{BDZ}^{\mathrm{T}}$ is a member of the genus Amycolatopsis (Fig. 1); a bootstrap value of $89 \%$ supports the assessment that it forms a distinct line with the $A$. methanolica subclade. The $16 \mathrm{~S}$ rDNA sequence similarities between strain $1 \mathrm{BDZ}^{\mathrm{T}}$ and

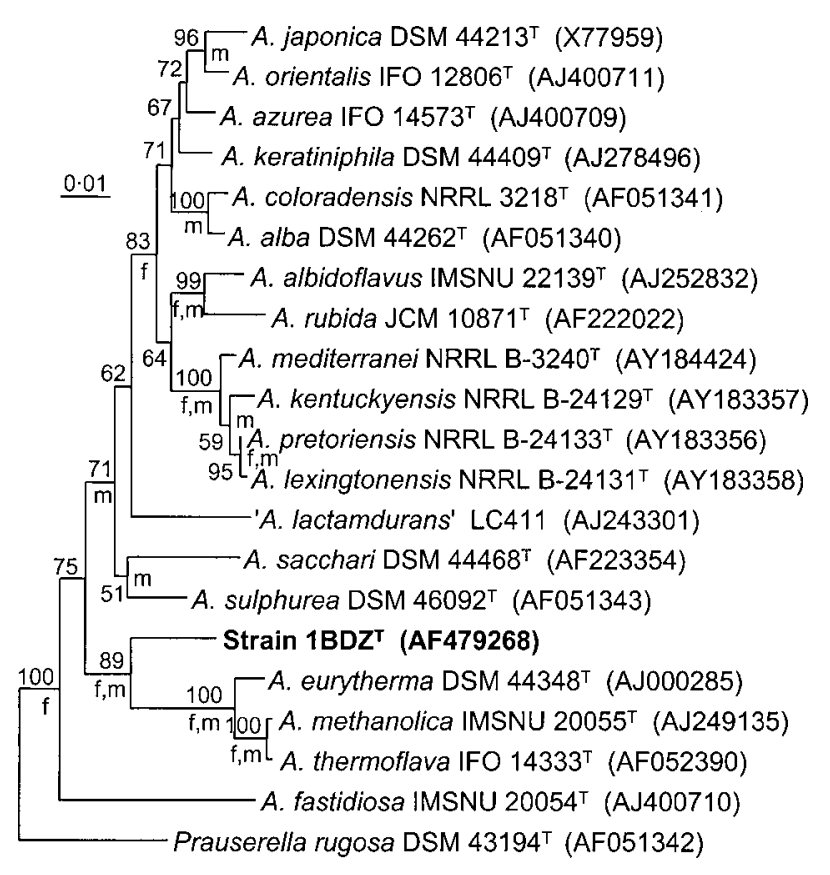

Fig. 1. Neighbour-joining tree (Saitou \& Nei, 1987) based on almost complete $16 \mathrm{~S}$ rDNA sequences showing the phylogenetic position of strain $1 \mathrm{BDZ}^{\top}$ within the radiation of Amycolatopsis species. Branches that were also recovered using the least-squares (Fitch \& Margoliash, 1967) and maximumlikelihood (Felsenstein, 1981) methods are respectively indicated by the letters $f$ and $m$. Numbers at nodes indicate percentage levels of bootstrap support based on a neighbour-joining analysis of 1000 resampled datasets; only values over $50 \%$ are given. Bar, $0 \cdot 01$ substitutions per nucleotide position. 
its nearest neighbours, the three thermophilic species A. methanolica, A. thermoflava and A. eurytherma, were respectively $96 \cdot 40,96 \cdot 32$ and $96 \cdot 16 \%$. Similarity values with other members of the genus Amycolatopsis were in the range $93 \cdot 86-95 \cdot 99 \%$. Thus, the unique phylogenetic position and moderately low $16 \mathrm{~S}$ rDNA sequence similarities indicate that strain $1 \mathrm{BDZ}^{\mathrm{T}}$ represents a novel taxon within the genus Amycolatopsis.

The chemotaxonomic data for strain $1 \mathrm{BDZ}^{\mathrm{T}}$ are consistent with its assignment to the genus Amycolatopsis. It contained meso-diaminopimelic acid as the wall diamino acid and arabinose and galactose as major wall sugars (type IV cell wall, according to Lechevalier \& Lechevalier, 1980); tetrahydrogenated menaquinones with nine isoprene units were the predominant isoprenoid quinones. The phospholipid pattern consisted of major amounts of phosphatidylethanolamine (a taxonomically significant phospholipid) and minor amounts of phosphatidylglycerol and phosphatidylinositol. The cellular fatty acid profiles included a large amount of 14-methylpentadecanoic acid (i-C16:0; 50.3\% of total). Considerable amounts of 13-methylpentadecanoic acid (ai-C16:0;3.6\%), hexadecanoic acid (C16:0;21.7\%), 14-methylhexadecanoic acid (ai-C17:0; $12 \cdot 4 \%$ ), heptadecanoic acid (C17:0; 8.5\%) and octadecanoic acid (C18:0; $3.7 \%)$ were also present. The organism did not contain mycolic acids.

The classification of strain $1 \mathrm{BDZ}^{\mathrm{T}}$ in the genus Amycolatopsis is also supported by phenotypic and morphological characteristics. The organism is a non-motile, Grampositive, not acid-alcohol-fast, catalase-positive actinomycete; it forms branched substrate mycelium that fragments into rod-like elements and carries sparse to moderate, white aerial hyphae that differentiate into long chains of sporelike structures. A combination of phenotypic properties easily distinguishes this strain from representatives of its nearest neighbours, the A. methanolica subclade (Table 1), and also from those of all Amycolatopsis species with validly published names. It is mesophilic, growing well in both aerobic and anaerobic conditions over a wide $\mathrm{pH}$ range $(\mathrm{pH} 6 \cdot 0-10 \cdot 0)$ and over a wide range of $\mathrm{NaCl}$ concentrations $(0 \cdot 5-7 \%, \mathrm{w} / \mathrm{v})$. Weak growth also occurs on $10 \%$ $\mathrm{NaCl}$. Additional physiological characteristics are shown in Table 1.

On the basis of phenotypic, chemotaxonomic and phylogenetic data, strain $1 \mathrm{BDZ}^{\mathrm{T}}$ merits recognition as a novel species of Amycolatopsis. We propose the name Amycolatopsis palatopharyngis sp. nov. for this taxon.

\section{Description of Amycolatopsis palatopharyngis sp. nov.}

Amycolatopsis palatopharyngis (pa.la.to.pha.ryn'gis. N.L. gen. n. palatopharyngis of the palatopharynx).

The organism forms branched yellow to yellow-brown substrate mycelium that fragments into rod-like elements.
Table 1. Differential phenotypic characteristics of $A$. palatopharyngis sp. nov. $1 \mathrm{BDZ}^{\top}$ and its nearest phylogenetic neighbours

Strains: 1, strain $1 \mathrm{BDZ}^{\mathrm{T}}$; 2, A. eurytherma DSM $44348^{\mathrm{T}} ; 3$, A. methanolica IMSNU $20055^{\mathrm{T}} ; 4$, A. thermoflava IFO $14333^{\mathrm{T}}$. Data for reference type strains were taken from Kim et al. (2002). +, Positive or present; w, weakly positive; -, negative or absent. All strains were positive for acid production from adonitol, mesoerythritol, (+)-D-fructose, (+)-D-galactose, (+)-D-trehalose and $(+)$-D-xylose and growth on $5 \% \mathrm{NaCl}(\mathrm{w} / \mathrm{v})$. All of the strains were negative for acid production from (+)-D-maltose and production of amylase.

\begin{tabular}{|c|c|c|c|c|}
\hline Characteristic & 1 & 2 & 3 & 4 \\
\hline Anaerobic growth & + & - & - & - \\
\hline Production of soluble pigment & - & - & - & + \\
\hline \multicolumn{5}{|l|}{ Acid production from: } \\
\hline$(+)$-L-Arabinose & + & + & - & + \\
\hline$(+)$-D-Cellobiose & - & + & + & + \\
\hline Dextrin & - & $\mathrm{W}$ & - & - \\
\hline meso-Inositol & + & + & - & - \\
\hline$(+)$-D-Lactose & - & $\mathrm{W}$ & - & + \\
\hline$(-)$-D-Mannitol & - & + & + & + \\
\hline$(+)$-D-Melibiose & - & - & - & + \\
\hline Methyl $\alpha$-D-glucoside & - & - & - & + \\
\hline$(+)$-D-Raffinose & + & - & - & + \\
\hline$(+)$-L-Rhamnose & - & + & + & - \\
\hline Salicin & - & - & $\mathrm{W}$ & + \\
\hline (-)-D-Sorbitol & - & + & + & + \\
\hline$(-)$-D-Sucrose & - & - & + & - \\
\hline \multicolumn{5}{|l|}{ Decomposition of: } \\
\hline Aesculin & - & - & $\mathrm{W}$ & + \\
\hline Allantoin & - & + & + & + \\
\hline Casein & + & + & - & + \\
\hline Gelatin & + & + & + & - \\
\hline Hypoxanthine & + & $\mathrm{W}$ & + & + \\
\hline Xanthine & + & - & - & + \\
\hline \multicolumn{5}{|l|}{ Growth at: } \\
\hline $10^{\circ} \mathrm{C}$ & + & - & - & - \\
\hline $45^{\circ} \mathrm{C}$ & - & + & + & + \\
\hline \multicolumn{5}{|l|}{ Production of: } \\
\hline Nitrate reductase & + & + & + & - \\
\hline Urease & $\mathrm{W}$ & + & - & + \\
\hline
\end{tabular}

White aerial mycelium is produced, sparsely on Bennett's, glucose/yeast extract/malt extract and brain heart infusion agars and moderately on inorganic salts/starch agar. The aerial mycelium differentiates into long chains of sporelike structures. Diffusible pigments are not produced. Facultatively anaerobic and catalase-positive. Growth occurs between $\mathrm{pH} 6$ and 10, between 0.5 and $10 \% \mathrm{NaCl}$ and between 10 and $40^{\circ} \mathrm{C}$, but not at $45^{\circ} \mathrm{C}$. Acid is produced from adonitol, (+)-L-arabinose, meso-erythritol, $(+)$-D-fructose, (+)-D-galactose, meso-inositol, (+)-Draffinose, $(+)$-D-trehalose and $(+)$-D-xylose, but not from (+)-D-cellobiose, dextrin, (+)-D-lactose, (+)-D-maltose, 
(-)-D-mannitol, (+ )-D-melezitose, (+ )-D-melibiose, methyl $\alpha$-D-glucoside, (+)-L-rhamnose, salicin, (-)-Dsorbitol or (-)-D-sucrose. Casein, gelatin, hypoxanthine, L-tyrosine and xanthine are degraded, but aesculin, allantoin and starch are not. Exhibits nitrate reductase and weak urease activity. Resistant to ampicillin $(10 \mu \mathrm{g})$, carbenicillin $(100 \mu \mathrm{g})$ and cephalothin $(30 \mu \mathrm{g})$, but not to acetylspiramycin $(15 \mu \mathrm{g})$, chloramphenicol $(30 \mu \mathrm{g})$, clarithromycin $(15 \mu \mathrm{g})$, doxycycline $(30 \mu \mathrm{g})$, gentamicin $(10 \mu \mathrm{g})$, kanamycin $(30 \mu \mathrm{g})$, midecamycin $(15 \mu \mathrm{g})$, minocyline $(30 \mu \mathrm{g})$, novobiocin $(5 \mu \mathrm{g})$, penicillin (10 IU), rifampicin $(5 \mu \mathrm{g})$, streptomycin $(10 \mu \mathrm{g})$ or tobramycin $(10 \mu \mathrm{g})$. Chemotaxonomic characteristics are typical of those for the genus Amycolatopsis. The $\mathrm{G}+\mathrm{C}$ content of the DNA is $65.8 \mathrm{~mol} \%$ ( $T_{\mathrm{m}}$ method).

The type strain, $1 \mathrm{BDZ}^{\mathrm{T}}\left[=\mathrm{AS} 4.1729^{\mathrm{T}}\right.$ (Chinese General Microbiological Collection Centre $)=\operatorname{PCM~} 2600^{\mathrm{T}}$ (Polish Collection of Microorganisms)], was isolated from the infected palatopharyngeal mucosa of an elderly human patient.

\section{Acknowledgements}

This work was supported by the Polish Academy of Sciences-Chinese Academy of Sciences Exchange Scheme and the Polish Committee for Scientific Research (grant 3-PO5A-007-23). The authors are grateful to Professor M. Goodfellow for offering some suggestions. Special thanks are due to Jolanta Pawlowska MSc (District Hospital in Plock, Poland) for sending the clinical isolates for identification.

\section{References}

Al-Musallam, A. A., Al-Zarban, S. S., Fasasi, Y. A., Kroppenstedt, R. M. \& Stackebrandt, E. (2003). Amycolatopsis keratiniphila sp. nov., a novel keratinolytic soil actinomycete from Kuwait. Int J Syst Evol Microbiol 53, 871-874.

Barreiro, C., Pisabarro, A. \& Martin, J. F. (2000). Characterization of the ribosomal rrnD operon of the cephamycin-producer 'Nocardia lactamdurans' shows that this actinomycete belongs to the genus Amycolatopsis. Syst Appl Microbiol 23, 15-24.

Chun, J. \& Goodfellow, M. (1995). A phylogenetic analysis of the genus Nocardia with $16 \mathrm{~S}$ rRNA gene sequences. Int J Syst Bacteriol 45, 240-245.

Chun, J., Kim, S. B., Oh, Y. K. \& 7 other authors (1999). Amycolatopsis thermoflava sp. nov., a novel soil actinomycete from Hainan Island, China. Int J Syst Bacteriol 49, 1369-1373.

Collins, M. D. (1985). Isoprenoid quinone analyses in bacterial classification and identification. In Chemical Methods in Bacterial Systematics, pp. 267-287. Edited by M. Goodfellow \& D. E. Minnikin. London: Academic Press.

de Boer, L., Dijkhuizen, L., Grobben, G., Goodfellow, M., Stackebrandt, E., Parlett, J. H., Whitehead, D. \& Witt, D. (1990). Amycolatopsis methanolica sp. nov., a facultatively methylotrophic actinomycete. Int J Syst Bacteriol 40, 194-204.

Embley, M. T., Smida, J. \& Stackebrandt, E. (1988). The phylogeny of mycolate-less wall chemotype IV actinomycetes and description of Pseudonocardiaceae fam. nov. Syst Appl Microbiol 11, 16-19.

Felsenstein, J. (1981). Evolutionary trees from DNA sequences: a maximum likelihood approach. J Mol Evol 17, 368-376.
Felsenstein, J. (1985). Confidence limits on phylogenies: an approach using the bootstrap. Evolution 39, 783-791.

Felsenstein, J. (1993). PHYLIP (phylogenetic inference package) version 3.5c. Distributed by the author. University of Washington, Seattle, USA.

Fitch, W. M. \& Margoliash, E. (1967). Construction of phylogenetic trees: a method based on mutation distances as estimated from cytochrome $c$ sequences is of general applicability. Science 155, 279-284.

Goodfellow, M., Brown, A. B., Cai, J., Chun, J. \& Collins, M. D. (1997). Amycolatopsis japonicum sp. nov., an actinomycete producing $(\mathrm{S}, \mathrm{S})-N, N^{3}$-ethylenediaminedisuccinic acid. Syst Appl Microbiol 20 78-84.

Goodfellow, M., Kim, S. B., Minnikin, D. E., Whitehead, D., Zhou, Z.-H. \& Mattinson-Rose, A. D. (2001). Amycolatopsis sacchari sp. nov., a moderately thermophilic actinomycete isolated from vegetable matter. Int J Syst Evol Microbiol 51, 187-193.

Gordon, R. E., Barnett, D. A., Handerhan, J. E. \& Pang, C. H.-N. (1974). Nocardia coeliaca, Nocardia autotrophica, and the nocardin strain. Int J Syst Bacteriol 24, 54-63.

Hasegawa, T., Takizawa, M. \& Tanida, S. (1983). A rapid analysis for chemical grouping of aerobic actinomycetes. J Gen Appl Microbiol 29, 319-322.

Henssen, A., Kothe, H. W. \& Kroppenstedt, R. M. (1987). Transfer of Pseudonocardia azurea and "Pseudonocardia fastidiosa" to the genus Amycolatopsis, with emended species description. Int J Syst Bacteriol 37, 292-295.

Huang, Y., Qi, W., Lu, Z., Liu, Z. \& Goodfellow, M. (2001). Amycolatopsis rubida sp. nov., a new Amycolatopsis species from soil. Int J Syst Evol Microbiol 51, 1093-1097.

Huang, Y., Wang, L., Lu, Z., Hong, L., Liu, Z., Tan, G. Y. A. \& Goodfellow, M. (2002). Proposal to combine the genera Actinobispora and Pseudonocardia in an emended genus Pseudonocardia, and description of Pseudonocardia zijingensis sp. nov. Int J Syst Evol Microbiol 52, 977-982.

Jones, K. L. (1949). Fresh isolates of actinomycetes in which the presence of sporogenous aerial mycelia is a fluctuating characteristic. J Bacteriol 57, 141-145.

Kim, S. B. \& Goodfellow, M. (1999). Reclassification of Amycolatopsis rugosa Lechevalier et al. 1986 as Prauserella rugosa gen. nov., comb. nov. Int J Syst Bacteriol 49, 507-512.

Kim, B., Sahin, N., Tan, G. Y. A., Zakrzewska-Czerwinska, J. \& Goodfellow, M. (2002). Amycolatopsis eurytherma sp. nov., a thermophilic actinomycete isolated from soil. Int $J$ Syst Evol Microbiol 52, 889-894.

Kimura, M. (1980). A simple method for estimating evolutionary rates of base substitutions through comparative studies of nucleotide sequences. J Mol Evol 16, 111-120.

Labeda, D. P. \& Kroppenstedt, R. M. (2000). Phylogenetic analysis of Saccharothrix and related taxa: proposal for Actinosynnemataceae fam. nov. Int J Syst Evol Microbiol 50, 331-336.

Labeda, D. P., Donahue, J. M., Williams, N. M., Sells, S. F. \& Henton, M. M. (2003). Amycolatopsis kentuckyensis sp. nov., Amycolatopsis lexingtonensis sp. nov. and Amycolatopsis pretoriensis sp. nov., isolated from equine placentas. Int J Syst Evol Microbiol 53, 1601-1605.

Lechevalier, H. A. \& Lechevalier, M. P. (1980). The chemotaxonomy of actinomycetes. In Actinomycete Taxonomy, pp. 277-284. Society for Industrial Microbiology Special Publication no. 6. Edited by A. Dietz \& D. W. Thayer. Arlington, VA: Society for Industrial Microbiology. 
Lechevalier, M. P., Prauser, H., Labeda, D. P. \& Ruan, J.-S. (1986). Two new genera of nocardioform actinomycetes: Amycolata gen. nov. and Amycolatopsis gen. nov. Int J Syst Bacteriol 36, 29-37.

Lee, S. D. \& Hah, Y. C. (2001). Amycolatopsis albidoflavus sp. nov. Int J Syst Evol Microbiol 51, 645-650.

Marmur, J. \& Doty, P. (1962). Determination of base composition of deoxyribonucleic acid from its thermal denaturation temperature. J Mol Biol 5, 109-118.

Minnikin, D. E., Hutchinson, I. G., Caldicott, A. B. \& Goodfellow, M. (1980). Thin-layer chromatography of methanolysates of mycolic acid-containing bacteria. J Chromatogr 188, 221-233.

Minnikin, D. E., O'Donnell, A. G., Goodfellow, M., Alderson, G., Athalye, M., Schaal, A. \& Parlett, J. H. (1984). An integrated procedure for the extraction of isoprenoid quinones and polar lipids. J Microbiol Methods 2, 233-241.

Paściak, M., Ekiel, I., Grzegorzewicz, A., Mordarska, H. \& Gamian, A. (2002). Structure of the major glycolipid from Rothia dentocariosa. Biochim Biophys Acta 1594, 199-205.
Saitou, N. \& Nei, M. (1987). The neighbor-joining method: a new method for reconstructing phylogenetic trees. Mol Biol Evol 4, 406-425.

Shirling, E. B. \& Gottlieb, D. (1966). Methods for characterization of Streptomyces species. Int J Syst Bacteriol 16, 313-340.

Thompson, J. D., Gibson, T. J., Plewniak, F., Jeanmougin, F. \& Higgins, D. G. (1997). The CLUSTAL_X windows interface: flexible strategies for multiple sequence alignment aided by quality analysis tools. Nucleic Acids Res 25, 4876-4882.

Warwick, S., Bowen, T., McVeigh, H. \& Embley, T. M. (1994). A phylogenetic analysis of the family Pseudonocardiaceae and the genera Actinokineospora and Saccharothrix with $16 \mathrm{~S}$ rRNA sequences and proposal to combine the genera Amycolata and Pseudonocardia in an emended genus Pseudonocardia. Int J Syst Bacteriol 44, 293-299.

Wu, C., Lu, X., Qin, M., Wang, Y. \& Ruan, J. (1989). Analysis of menaquinone compound in microbial cells by HPLC. Microbiology (English translation of Mikrobiologiya) 16, 176-178. 